\title{
From aspect to evidentiality: the subjectification path of the French semi-copula se faire and its Spanish cognate hacerse
}

\author{
Peter Lauwers \\ (University of Ghent ${ }^{a} ;$ K.U.Leuven ${ }^{b}$ ) \\ $\&$ \\ Claude Duée \\ (University of Castilla - La Mancha ${ }^{\mathrm{c}}$ )
}

Corresponding author: Peter Lauwers

\section{a}

Department of French

Ghent University

Blandijnberg 2

9000 Ghent

Belgium

peter.lauwers@ugent.be

Telephone: ++32(0)92689891

b

French and Italian Linguistics

University of Leuven

Blijde-Inkomststraat 21

3000 Leuven

Belgium

peter.lauwers@arts.kuleuven.be

Telephone: ++32(0)16324793

++32(0)16324767

c

Departamento de Filología Moderna

Facultad de Letras

Universidad de Castilla-La Mancha (UCLM)

Avda. Camilo José Cela, s/n. Campus Universitario

13071 Ciudad Real

Spain

Claude.Duee@uclm.es

\begin{abstract}
In the literature on evidentiality and epistemic modality, semi-copular verbs have hardly been discussed. One of these unstudied semi-copulas is French se faire ('become'), a pronominal verb taking a subject complement. It can be considered a product of the conjoined action of lexicalization and grammaticalization of the reflexive construction. Although its basic meaning is aspectual, expressing a change of state ('become'), it is nowadays developing a non-dynamic meaning, involving no change of state at all.

This paper addresses two central questions:
\end{abstract}


(i) what is the exact meaning effect of se faire compared to other evidential semi-copulas such as sembler and paraître?

(ii) how does this usage relate to the other usages of this multilayered verb and how exactly is subjectification taking place?

As to (i), it will be shown that, although se faire expresses indirect evidentiality based on inference, it does not express appearance, unlike verbs such as 'seem'. Rather, it has a factive meaning that comes rather close to what has been called direct evidentiality. As to (ii), it will be argued that, in a first stage, se faire has been increasingly used in contexts that display subjective perspectivation of the change of state. Then, it has lost its dynamic meaning by means of the mechanism of virtual change. On the whole, this evolution attests a new subjectification path leading from aspect (change of state) to evidentiality, which, interestingly, is confirmed by the Spanish cognate verb hacerse ('become').

Key words: aspect, evidentiality, change of state, copula, subjectification, subjectivity

\section{Introduction}

In the literature on evidentiality and (epistemic) modality, much has been published on raising verbs such as sembler, paraître, menacer and promettre (Ruwet, 1972; Tasmowski, 1989; Cornillie, 2004; Verhagen, 2000 and many others). Some of these also have (semi-) copular ${ }^{1}$ usages (Lamiroy \& Melis, 2005 ; Porroche, 1990 ; Hengeveld, 1992) which equally express evidential meaning effects (e.g. sembler, paraître, s'avérer, se révéler), although they have hardly ${ }^{2}$ been considered in the literature on evidentiality (see for instance Cornillie, 2007). This is nothing more than a consequence of the more general lack of interest in semi-copulas, compared to the huge number of studies both on (semi-)auxiliairies and the many faces of the copula be.

One of the most intriguing cases of these little-studied semi-copulas is French se faire, a pronominal verb taking a subject complement. It can be considered a product of the conjoined action of lexicalization and grammaticalization of the reflexive construction. Its basic meaning is aspectual, marking a change of state ('become'):

(1) L'eau se fait rare

'Water is becoming rare'

In (1) the water used to be abundant, but, now, it is rather scarce. Interestingly, this multilayered verb has also developed a non-dynamic meaning, involving no change of state at all:

(2) Incroyablement compact [...], il [= le baladeur mp3] se fait très discret.

'Incredibly compact [...], it [= mp3-player] looks very discreet'

In (2), the interpretation is clearly non-dynamic, as shown by the context: because the Mp3 is small, it looks discreet. There is no change of state of play, going from non-discreet to discreet. It is clear, from the outset, that the interpretation of such examples, especially those appearing in bridging contexts (cf. infra), will require careful scrutiny of the context. The recent use illustrated in (2). may be called evidential, since se faire suggests that the speaker/experiencer makes an assertion based on sensory evidence: something appears to her/him as discreet, short, etc. (see 3.2.). It is interesting to note that a similar polysemy is attested in its Spanish counterpart hacerse:

(1') El agua se hace escasa .

'Water is getting rare'

(2') El viaje se hizo corto.

'The trip seemed short (to us)'

\footnotetext{
${ }^{1}$ See Lamiroy \& Melis (2005) for a discussion of the properties of semi-copulas in French.

${ }^{2}$ By contrast, some studies have been dealing with the copular usages of perception verbs in English, such as look (Miller, 2005; Gisborne \& Holmes, 2007).
} 
The case of se faire (and its Spanish cognate) attests a new subjectification path leading from aspect (change of state) to evidentiality. In this regard, the following questions need to be addressed:

(i) what is the exact evidential meaning effect of se faire compared to other evidential semi-copulas such as sembler and paraitre?

(ii) how does this usage relate to the other usages of this multilayered verb and how exactly is subjectification taking place?

Before tackling these questions $(\S 3 . ; \S 4$.), it is necessary to provide the whole picture of the many uses of se faire $(\S 2$.). The paper will focus on se faire, but it will be argued that its Spanish cognate hacerse confirms the central results of our study ( $\$ 5$.).

Our study is based on extensive corpus research in PoS-tagged and lemmatized corpora of written language (Frantext <French> and Corpus del español <Spanish>, both restricted to the $20^{\text {th }}$ century), completed by some smaller corpora of spoken (C-Oral-rom) and written (Adesse) language and by Google searches (realized in November 2008). In order to ensure acceptability of the corpus examples, we submitted them to three native speakers, who evaluated them by means of the usual four-point scale (*; ??; ?; ok).

\section{Se faire: several constructions, several meanings}

Se faire (like its Spanish cognate hacerse) is known as a change of state copula meaning 'to become'. It is a less frequent near synonym of the 'generic' change of state copula devenir. If we take a closer look at this multi-layered verb, several constructions and meaning effects can be distinguished. To classify them, the following parameters will be put to use:

[ \pm dynamic] : do the verb and its predicative complement express a change of state (dynamic) or not ?

$[ \pm \text { subject control }]^{3}:$ is the process expressed by the verb and its predicative complement controlled (wanted) by the grammatical subject or not? ${ }^{4}$

[ \pm reflexive]: can the pronominal construction be analyzed as the reflexive variant of a corresponding transitive construction?

(3) Jean $s e$ croit apte à faire ce travail Jean le croit apte à faire ce travail.

'Jean considers himself able to do the job $\sim$ Jean considers him able to do the job'.

Some additional criteria will be adduced, such as the morphosyntactic category of the predicative complement (adjective, bare noun, noun phrase) and the intrinsic or extrinsic nature of the change of state. As to the latter, Spanish has a specific copula, viz. ponerse 'to get ADJ', which encodes «temporary changes in non-essential characteristics » (Eddington, 1999): se puso pensativa ('she adopted a thoughtful air').

In what follows, we will start from the possible combinations of the features, $[ \pm$ dynamic] and [ \pm subject control]. One of the four combinations logically possible is not attested for se faire, viz. [-dynamic] and [+subject control $]^{5}$.

The quantitative results of the study of the Frantext corpus (955 examples $\left.{ }^{6}\right)$ are summarized in table (1):

\footnotetext{
${ }^{3}$ The control exerted by the subject depends on the subject (animate vs inanimate) and the predicative complement (an animate subject can be deprived of control : Jean se fait vieux 'John is getting old'). This semantic parameter can be tested distributionally by adding adjuncts such as par/de lui-même 'by himself', agent-oriented manner adverbials (such as expres(sément) 'deliberately', prudemment 'cautiously') and goaloriented adjuncts (pour + infinitive 'in order to' ) or by embedding se faire as a complement of s'efforcer de 'to do one's best to'.

4 "[whether] the change comes about as a result of intentional effort, or whether the change occurs passively or unexpectedly" (Eddington, 1999).

${ }^{5}$ A possible example might be Les élèves sont très attentifs ('The pupils are very attentive').
} 


\subsection{Dynamic + subject control : ' $X$ does something so that $X$ becomes $Y^{\prime}$}

The first class of usages is characterized by the presence of a wilful animate subject that exerts control on the change of state. Note that about $41.1 \%$ of the corpus examples of se faire + adjective contain animate subjects.

\subsubsection{Reflexive : ' $X$ does something to $X$ so that $X$ becomes $Y$ '}

In $16.4 \%$ of the corpus instances (157 examples), se faire can still be considered a reflexive paraphrase of a transitive construction (both with adjectives and bare nouns):

(4) elle se fait belle 'she makes herself beautiful', especially 'she is putting on her make-up'

$<$ on la fait belle 'they make her beautiful'

This construction is only attested in Frantext with the following adjectives: beau (25 examples), joli (1 example) and désirable (1 example). In the case of bare nouns, one can further distinguish between 'autoproclamation' (9 examples; 0.9\%) and 'acts of selfdetermination' (124 examples; $13.0 \%$ ):

(5) Mobutu s'est fait président

'Mobutu has made himself president'

$<$ On l'a fait président.

'They made him president'

(6) Joseph s'est fait poète.

'Joseph has made himself a poet'

< Sa mère l'a fait poète ${ }^{7}$

poet'

Lit. His mother made him a poet, 'he has been strongly influenced by his mother in becoming a

In all these examples one clearly observes a change of state controlled by an animate (human) clausal subject, which is a necessary (though not a sufficient) condition. This construction is quite rare, as has been shown, especially in the case of adjectives.

\subsubsection{Non reflexive (' $X$ becomes $Y$ and $X$ bears [part of] the responsibility of the change of state')}

Most of the examples involving subject control have to be considered genuine intransitive constructions, without a transitive counterpart (261 examples; $27.3 \%$ ).

(7a) Olivier se souvint de l'époque où il prenait le métro avec sa maman. Là, pour bénéficier de la gratuité, il devait se faire petit. (Frantext)

'Olivier remembers the time when he took the subway with his mother. To benefit from free travel, he had to make himself small'.

(7b) $*\{$ Cela / Cette personne $\}$ le fait petit.

'That / That person makes him / it small'.

The meaning of this construction can be paraphrased as follows: ' $\mathrm{X}$ undergoes a change of state for which $\mathrm{X}$ is responsible or in which $\mathrm{X}$ bears part of the responsibility', but the

\footnotetext{
${ }^{6}$ These figures do not take into account the 47 examples of "mixed" attribution in the case of predicative Ns (bare nouns) and NPs in which an animate subject has been combined with an inanimate subject and vice versa (cf. table in section 4.1.).

${ }^{7}$ An attested example: C'est sa mère qui l'a fait poète ('It is his mother who made him a poete'). (http://lettres.lem.online.fr/lectures/kundera_la_vie_est_ailleurs.PDF)
} 
reflexive pronoun is not profiled any more as an autonomous (co-referential) participant role (patient or theme) undergoing a transformation. Importantly, the result of the intentional change is not permanent ${ }^{8}$. Unlike devenir, se faire does not alter the intrinsic characteristics of the subject. As it happens, Olivier does not really become a small person, he only adopts a posture in order to look very small.

Corpus examples fall into two categories:

A. Adjectives referring to the physical appearance of a person (cf. 7) ${ }^{9}$

petit 'small' (23), léger 'light' (1), minuscule 'minuscule' (2), discret 'discreet' (1), furtif

'stealthy' (1), nu 'nude' (2), rare 'rare' (24), fuyant 'evasive' (1); propre 'clean' (1); semblable

à ('[a posture] similar to') (1); habile 'handy' (1)

B. Adjectives referring to a temporary state of mind or a certain air adopted by a person:

humble 'humble' (7), attentif 'attentive' (3), aimable 'gentle' (4), agressif 'aggressive' (3), dur 'hard' (3), menaçant 'threatening' (2), paternel 'fatherly' (2) ; précis 'precise' (2); souple 'flexible' (2) ; suppliant 'beseeching' (2) ; violent 'violent' (2) ; mou 'sweet' (2) ; ironique 'ironical' (2) ; grave 'serious' (2); gentil 'gentle' (2); actif 'active' (2) + other (1 instance each)

Here are two examples of the type B:

(8) elle se fit méchante (Chabrol.J-P / Je t'aimerai sans vergogne/1967).

'She got nasty'

(9) sa voix se fit solennelle (Modiano. P / Les boulevards de ceinture/1972)

'His voice became solemn'

Very often (92 examples out of 340 examples with inanimate subjects). the subject is inanimate, though indirectly referring to a human referent by means of a metonymic relation (voice of a person $=$ the person himself/herself, cf. 9). As change appears to be momentary, se faire often tends to be interpreted as 'adopting an affected, fake attitude'. Such implicature is not available in the case of devenir:

(10) Mais ce n'est qu'un jeu ! Romain se fait désinvolte par passion (Kristeva, J./Les Samourais /1990) 1990)

'But this is only a game! Romain presents himself as unaffected by passion'.

The type B (103 examples, $10.8 \%$ ) is more frequent than the type A (55 examples, 5.8\%) and has a very high type frequency, whereas the type $\mathrm{A}$ is restricted to a small set of very frequent types.

Further, dynamic se faire involving subject control also occurs with definite NPs (103 examples, $10.8 \%$ ):

(11) se faire les héros d'une résistance nationale contre l'envahisseur.

'to make themselves the heroes of the national resistance against the conqueror'

Not less than 60 examples $(=58 \%)$ concern nouns belonging to the semantic paradigm of 'defender, champion, advocate'. In most examples the status is found rather inappropriate and hence not really intrinsic: the subject referent is only "usurping" the status of champion, defender, etc.

\footnotetext{
${ }^{8}$ Strikingly, intentional intrinsic change of state was possible in earlier stages of the language, as revealed by some examples of the Frantext corpus dating before 1600: e.g. il n'y a chose plus profitable à l'homme pour se faire riche ('there is nothing more profitable to man to make himself rich'); L'homme se fait bon ('a man <generic> becomes good'). Most of the (rare) examples found in the Frantext corpus (before 1950), are rejected nowadays by native speakers. Only three examples are still acceptable, although they sound very archaic: e.g. afin qu'ils [= les riches] se fissent pauvres 'so that they [= the rich] make themselves poor'.

${ }^{9}$ Six philosophical examples involve se faire in contexts in which God and man are considered as entities capable of shaping theirselves.
} 


\subsection{Dynamic, no subject control: ' $X$ becomes $Y$ '}

In case of absence of subject control (54.2\% of the corpus examples), the meaning of se faire - which has become a truly intransitive verb - resembles very much that of devenir, although the distributional scope of the latter is nearly unlimited, while se faire only has a very restricted use. In some cases, speakers do not feel (or are not able to explicate) any difference between se faire and devenir, except a difference in register (se faire belongs to a higher register): il se fait / devient vieux ('he is getting old'), l'eau se fait / devient rare ('water is becoming rare'), les temps deviennent / se font durs ('times are getting tough'). We will try to untangle this delicate issue by means of corpus research (see section 4.). For the moment, it will suffice to give two examples, the one involving an inanimate subject (12), the other an animate subject (13):

(12) Les temps se font durs.

'Times are getting tough'

(13) Pierre se fait vieux.

'Peter is getting old'

In the remainder of this paper, we will not take into consideration the animate type, which appears to be infrequent (animate subject: $3.8 \%$; inanimate subject: $35.6 \%$ ) and very restricted from a lexical point of view. Only vieux 'old' (29), grand 'tall' (1), chauve 'bald' (1), gras/poussif 'fat' (1), aveugle 'blind' (1), médiocre 'mediocre' (1), mobile 'mobile' (1) and sédentaire 'sedentary' (1) (the latter two in relation to the evolution of species) are attested in Frantext. Moreover, most of these examples have been rejected by our native speakers, except those including vieux 'old' and, only in context, mobile 'mobile' and sédentaire 'sedentary'. This observation suggests that se faire vieux + human referent is nothing more than an isolated remnant of an earlier stage of the language. For instance, the example provided by the first edition of the Dictionnaire de l'Académie française (1692) is completely unused nowadays:

(14) *Un enfant qui se fait grand.

Lit. A child who is getting tall. 'A child who is growing up'

It appears, thus, that se faire is unable to cancel the volitional element contained in human subjects in order to allow for an uncontrolled change of state reading, except in the case of vieux 'old'.

Finally, the use of se faire as a quasi-synonym of devenir (without subject control) is also possible with bare nouns involving inanimate subjects:

(15) Le jeu se fait épreuve.

'The game becomes a test'

This very literary (poetic) usage of bare inanimate nouns (Lauwers, 2007) reaches a frequency of 1,76 per million words (136 examples).

\subsection{Non-dynamic, no subject control: evidential se faire}

Up to now, se faire has been described as a dynamic aspectual verb, marking a change of state, involving control or absence of control and yielding an intrinsic or non intrinsic result. However, as illustrated in (2a), se faire is developing nowadays a non-dynamic, evidential meaning, involving no change of state at all. As it happens, there is no evolution from [discreet] to [+ discreet]. As a result, substitution by devenir is totally impossible. In the subsequent sections, we will discuss in detail this remarkable evidential use, which only allows inanimate subjects. 


\section{Evidential se faire}

First, we will try to circumscribe the evidential use of se faire on the basis of corpus observations (3.1.). Then we will elaborate the specific meaning effect (3.2.) of evidential se faire and some of its morpho-syntactic properties, in contrast with sembler and paraitre 'seem' (3.3.).

\subsection{Corpus data}

Evidential se faire is very recent ${ }^{10}$. As a result, not even one example has been found in the Frantext corpus: all Frantext examples still express dynamic aspect ('become'). On the Internet, by contrast, this use seems to be fairly widespread:

(16) [cell phone] le fin boitier en aluminium [...] sur lequel coulisse un immense écran, tel un miroir, se fait très agréable lors de sa prise en main. (www.pixmania-pro.fr/fr/fr/lg/shine-ke970/494406/fiche.html)

'The fine aluminium case [...] over which an immense screen slides, a mirror as it were, feels very nice when you hold it in your hand'

Its numerical importance should not be underestimated. For instance, all 30 Google instances of se fait très discret 'discreet' (with inanimate subjects) turn out to be evidential ones. Many instances of se fait très rare 'rare' are ambiguous, but in at least two of them there is no objective change whatsoever. Moreover, 13 further examples of evidential usage have been found, although the total number of instances of se fait très $+\operatorname{adjective~}^{11}$ does not exceed 113 . In other words, 45 out of 113 examples involve no change of state at all.

Admittedly, a lot of examples attesting bridging contexts (a.o. Diewald, 2002) have been found, in which it is difficult to know whether there is still a change of state involved or not:

(17) Dans ce climat, loin de ma famille et des personnes qui peuvent m'aider de leurs conseils à mieux vivre ma vie chrétienne, l'aide de Dieu se fait très présente (www.opusdei.fr/art.php?p=26710)

'In these surroundings, far away from my family and from those people who can help me with their advice to live as a better Christian, God's help becomes very tangible'

On the one hand, the help of God is or seems to be very evident for this particular person at that particular moment. On the other hand, we might still interpret the presence of God from a change of state perspective: the presence of God is becoming more and more tangible as the person is turning in on herself.

The adjectives that combine with se faire belong to the semantic field of (auditory, visual, etc.) perception. Apart from the numerous examples of rare 'rare' and discret 'discreet', Google yields another 14 exemples of this usage. In 7 instances, the adjective belongs to the auditory field; the other examples involve the tactile (2), the visual (1) and the olfactory (1) domain. Three further examples are only loosely related to perception. As a corollary, they are hardly acceptable to many native speakers:

(18) Le lendemain matin, le réveil se fait très complexe. Après une soirée festive, les élèves ont bien des difficultés à se lever. (tele.ados.fr/news/star-academy-resume-week-end-21-22-octobre-

2006_article3206.html -)

'The morning after, waking up appears as very complex. After a night of partying, pupils have difficulty waking up'

\footnotetext{
${ }^{10}$ As a consequence, it is not attested in the major dictionaries such as Le (Petit) Robert and TLFi, although the latter does mention 'seem' as a possible paraphrase of the meaning of se faire ('commencer à être et paraître'). The examples, however, do not illustrate this non-dynamic meaning. What is actually meant here is what we have called 'perspectivized' change of state' (cf. 4.2.). To a certain extent, the definition provided by $T L F i$ confirms that there is a natural cline from 'perspectivized' change of state to appearance.

11 The insertion of a degree adverbial is the only possible way to limit the number of irrelevant Google instances.
} 
(19) Le plaisir de jouer est intact, le répertoire se fait très complet.

(www.westerncountryfriends.asso.fr/pages_primes/03album07b.htm; this page has disappeared from the web)

'The joy of playing is intact ; the repertoire appears as very complete'

As to the subject of the verb, the evidential interpretation is not attested with [+ human] referents. This means that the evidential usage is not yet strong enough to cancel the volition implied in animate subjects. Indeed, animate subjects immediately recall the dynamic construction with subject control:

(20) Je me fais très radical mais c'est juste pour faire débat.

'I'm adopting a very radical stand / I'm showing myself to be very radical, but only to fuel the debate'

\subsection{The semantics of evidential se faire : evidentiality without appearances}

Let us now take a closer look at the semantics of se faire. As is known, evidentiality has something to do with the multiple sources of information, that is with the evidence on which the speaker's stance is based (Dendale \& Tasmowski, 2001 ; Hassler, 2002 ; Aikhenvald, 2006; Ekberg \& Paradis eds, 2009). Much of the current debate turns around the formal encoding of this semantic category (Aikhenvald, 2006), its internal structure and its relation to other concepts like epistemic modality (Dendale \& Tasmowski, 2001; De Haan, 2001 ; Cornillie, 2009).

For our purpose it will suffice to recall that several kinds of evidentiality have been recognized (Chafe, 1986 ; Willet, 1988 ; etc.) and that se faire belongs to the field of indirect evidence, more specifically to the inferential type (Willet, 1988). The speaker/experiencer draws an inference on the basis of available (sensory) evidence. In this respect, se faire resembles other semi-copular verbs such as sembler 'seem', paraître 'seem', faire 'look' (+ adj.: elle fait vieille 'she looks old'; Delplanque, 2006; Lauwers, 2008) and, more specifically, the copular uses of perception verbs such as look (Miller, 2009). However, evidential se faire cannot simply be substituted by sembler / paraittre / faire. Contrary to these three verbs (and verbs such as look), the inference on which the statement is based cannot be cancelled :

(21a) *Le boîtier se fait agréable lors de sa prise en main, mais il ne l'est pas (en réalité)

'The case feels nice when you hold it in your hand, but (in fact) it isn't'.

(21b) vs. il \{fait / paraît \} vieux, mais il ne l'est pas (en réalité)

'He \{looks / seems $\}$ old, but (in fact) he isn't'.

The speaker would simply contradict him/herself. The reason for this is that se faire does not express appearance - which in the case of faire even tends towards counterfactuality (Lauwers, 2008 : 55). Instead, se faire has a factive meaning and comes rather close to what has been called direct evidentiality (Willet, 1988). The speaker has some sort of sensory evidence for the state of affairs he is describing: something hits the retina or the eardrum or shows up and offers itself to perception, providing "evidence" of a certain state of affairs. In the inferential process there is not much room for doubt. As a result, from the point of view of epistemic modality, the utterance is uttered with certainty. The following gradient can be established :

Table 1 
Interestingly, the factive orientation of se faire also appears in the impersonal construction with a subsequent complement clause :

(22) J'appuie la Commission européenne dans ses efforts [...] Or, il se fait que la réglementation communautaire en matière de pêche maritime n'est pas appliquée de façon uniforme par les différents États membres.

'I support the European Commission in its efforts [...]. However, it appears that the regulations of the Union with regard to sea fishing are not applied in the same way by all the member states'.

Of course, in this case, no predicative complement construction is involved.

\subsection{Morpho-syntactic aspects}

As se faire has acquired an evidential meaning, it might be the case that se faire behaves like other evidential copular verbs from a constructional point of view. This is however not the case, since two typical constructional templates are unavailable in the case of se faire + predicative complement: the dative explicating the experiencer and the impersonal construction with infinitives and complement clauses.

Let us first look at the dative. The expression of the experiencer (Engl. to X; dative) is a typical feature of evidential verbs such as sembler and paraître ('seem') (Miller, 2009, referring to Gisborne; see also Gisborne \& Holmes, 2007). If the experiencer remains unexpressed ("offstage"; Langacker, 1990: 7), it can very often be recovered contextually or situationally. With se faire, however, the formal expression of the dative is impossible for structural reasons. The incompatibility of the reflexive pronoun and the dative form of the personal pronoun falls within the scope of a more general restriction on the combination of certain (personal) pronouns, which is mentioned in all reference grammars:

"The clitic pronouns me, te, se, nous and vous cannot (except the expletive pronouns: $\$ 647$, e) be juxtaposed, nor be combined with the pronouns lui and leur" (Grevisse \& Goosse, 1993: 1044; our translation $^{12}$ )

Sentences such as *Le boitier se lui fait discret are clearly ungrammatical, as is the case of sentences such as *Tu me lui présenteras ('You will present me (to) him'). Moreover, the corresponding PP 'to $\mathrm{X}$ ' is not possible either :

(23) *Le boitier se fait discret à lui / aux spécialistes.

'The case appears discreet to him / to the specialists'.

The only way to explicitate the experiencer would be to use an adjunct phrase introduced by pour 'to' or aux yeux de 'in the eyes of':

(24) Pour eux / pour les spécialistes / aux yeux des spécialistes, le boitier se fait discret. (constructed example, checked by native speakers)

'To them / to the specialists / in the eyes of the specialists, the case appears discreet'.

Interestingly, in Spanish, there is no such restriction: the reflexive pronoun can be combined with personal pronouns (cf. § 5. infra).

Second, the impersonal construction, which is also typical of evidential verbs (Miller, 2009; Gisborne, 2000; Lauwers, 2007), is also blocked in the case of se faire + predicative complement:

(25) Il (me) \{semble/parait $\}$ essentiel \{de + infinitive / que complement clause

'It (to me) seems essential \{to infinitive / that-clause \}'

(26) *Il se fait nécessaire $\{d e+$ infinitive / que complement clause $)$

\footnotetext{
12 «Les pronoms conjoints me, te, se, nous et vous ne peuvent pas (sauf les pronoms explétifs : §647, e) se trouver juxtaposés deux à deux, ni se joindre aux pronoms lui et leur » (Grevisse \& Goosse, 1993: 1044).
} 
'It appears necessary\{to infinitive / that-clause \}'

As an evidential verb, it does not come as a surprise that se faire exhibits temporal and aspectual restrictions. For instance, compound forms expressing resultative aspect are not allowed, whereas they are not at all incompatible with dynamic se faire:

(27) *La MX-5 s'est faite très bruyante. (http://essais.autojournal.fr/video/1410302/text)

'The MX-5 comes across as very noisy'

vs. (28) L'Arema s'est faite très discrète depuis la crise politique (nah296.free.fr/Manandafy_afrique_express.htm)

'The Arema has become very discreet since the political crisis'.

Similar restrictions hold for the evidential use of faire + adjective (Lauwers, 2008). This restriction can be explained by the fact that the inferential sensory act on which the utterance is based requires simultaneity between the process and the conceptualizer. It cannot be done "afterwards", on the basis of the results of a process. Moreover, as known from the literature (Seuren, 2003; Cornillie, 2004, ch. 3,), the loss of perfect tenses can be considered one of the characteristics of decategorialization (Hopper \& Traugott, 1993: 103) within the process of auxiliariation / grammaticalization.

As to the simple and periphrastic future, no true restrictions seem to exist; the experience is simply postponed to the future:

(29) Logé dans un boîtier très compact, il se fera très discret dans une poche ou dans une sacoche. (www.caraudiovideo.com/index.php/.../59/)

'Housed in a very compact case, it will look very discreet in your pocket or in your handbag'

(30) EveryTrail [...] est une application GPS et appareil photos qui s'installe sur son mobile doté d'un GPS. Une fois lancé, il va se faire discret et enregistrer votre parcours grâce au GPS. (www.ziki.com/.../mobilitetouristique-photo-une-foule-de-gadgets-touristiques+8703412)

'EveryTrail [...] is a GPS application and photo camera that is installed on a mobile equipped with GPS. Once it is launched, it will appear very discreet and will register your route thanks to GPS'.

\section{From aspect to evidentiality}

The question that remains to be addressed is how this evidential interpretation has arisen from the aspectual meaning of se faire. To answer this question, it is necessary, first, to consider the global diachronic evolution of the predicative complement construction of se faire (4.1.). It will be argued that the decline of se faire has been accompanied by the rise of a subjective meaning effect, corresponding to the perspectivation of the change of state denoted by the verb (4.2.). Recently, this subjective perspectivation seems to have backgrounded the dynamic aspectual meaning, adding a new non-dynamic layer to the meaning of se faire + predicative complement (4.3.).

\subsection{Se faire: decline and deagentivisation}

In the Frantext corpus, restricted to the $20^{\text {th }}$ century $(77,406,645$ words), the construction $s e$ faire + predicative complement is represented as follows:

\section{Table 2}

On the whole, the global frequency of se faire has been constantly diminishing since the $16^{\text {th }}$ century (20.79 > 12.94 occ. per million words). This evolution has still continued during the $20^{\text {th }}$ century: $14.26(1900-1949)>11.02(1950-2000)$.

If we now compare the frequencies of adjectival complements with those taken from the period before 1600 (untagged corpus; 5,915,473 words) and that between 1830 and 1850 (tagged corpus; 20,237,193 words), some interesting observations can be made: 
Table 3

Whereas no significant difference can be observed regarding the global frequency of adjectival predicative complements, it is clear that se faire takes fewer animate subjects than in the past: $88 \%>63.7 \%>41 \%$. Recall that animate subjects are a conditio sine qua non to have a [+ control] reading, though not all animate subjects exert control on the change of state expressed by the verb and its predicative complement (e.g. Pierre se fait vieux 'Pierre is getting old'). For instance, the following corpus example dating back to the $16^{\text {th }}$ century is no longer acceptable:

(31) François polis se font meilleurs. / Est-ce pas une chose estrange / Par un soudain et nouveau change / Que les mauvais deviennent bons (Jean-Antoine de Baï / Mimes, enseignemens et proverbes, II / 1581)

'Polite Frenchmen become better / Isn't it a strange thing / by a sudden and new change / that the bad ones become good'

Note that at that time devenir and se faire could still alternate without any difference in meaning (se font meilleurs / deviennent bons).

\subsection{Perspectivation and 'subjective' change of state}

Dynamic se faire has been on the decline since 1600, an evolution still continuing today. As a result, several examples of the $20^{\text {th }}$ century section of the Frantext corpus have been found unacceptable by native speakers (cf. 2.2. above). Moreover, se faire is very often felt as being a somewhat old-fashioned verb, belonging to the literary register ${ }^{14}$. This impression is confirmed by the fact that some of its usages are very isolated from a synchronic point of view (il se fait vieux 'he is getting old'; elle se fait belle 'she makes herself beautiful'), which suggests that they may be remnants of a former 'productive' use.

Paradoxically, during its decline, which has been accompanied by a process of deagentivization (cf. Langacker, 1999b), se faire has also undergone a subjectification process (4.2.2.), which accounts for the very unpredictable distribution of dynamic se faire in contemporary French. Alongside this decline, the adjectives with which se faire can be combined have been restricted to a limited number of semantic fields sharing the feature "subjectivity", as we will show in 4.2.1.

\subsubsection{The distribution of se faire : adjectives}

The adjectives that occur in the Frantext corpus with uncontrolled dynamic se faire have been regrouped in six semantic categories ${ }^{15}$, which will be presented in detail.

\section{(a) Adjectives denoting (gradually) increased vs. reduced accessibility to perception}

\footnotetext{
${ }^{13}$ A similar evolution has been attested for Sp. hacerse (Davies corpus): $36 \%$ (16 ${ }^{\text {th }}$ century) $\rightarrow 15.4 \%\left(20^{\text {th }}\right.$ century).

${ }^{14}$ This impression is confirmed by the quasi absence of se faire + predicative complement in the C-Oral-Rom corpus of spoken French (300 000 words). Only two instances have been found (rare 'rare', beau 'beautiful'), which roughly corresponds to the same frequency. Its Spanish cognate is attested 8 times in the Spanish parallel corpus (same dimensions, same composition).

${ }^{15}$ The relevance of these categories has been confirmed by the analysis of the translation possibilities. Only in these categories literal translation of hacerse by se faire is possible. Only 6 examples of hacerse that can be translated by se faire fall outside their scope: les nuits se font tranquilles (tranquilas) 'the nights become calm'; cette information se fait obsolète (obsoleta) 'this information becomes obsolete'; Le commerce se fait multilatéral (multilateral) 'The trade becomes multilateral'; Le nihilisme se fait conservateur (conservador) 'Nihilism becomes conservative'; La science se fait normative (normativa) 'Science becomes normative'; Le mélodrame se fait politique (político) 'The melodrama becomes political'.
} 
These adjectives are particularly frequent in the Frantext corpus : 92 examples, i.e. 1,18 occ. per million words, or $37.1 \%$ of the 248 examples involving inanimate subjects. The following adjectives are the more frequent ones:

rare 'rare' (43), sensible 'perceptible' (3), visible 'visible' (3), précis 'precise' (3), opaque 'opaque' (3), évident 'evident' (3), nombreux 'numerous' (2), discret 'discreet' (2), clair 'clear' (2); imperceptible 'imperceptible', invisible 'invisible', présent 'present, tangible', réel 'real', vivant 'vivid', etc.

Note the very high frequency of rare. This holds also for the Google corpus ${ }^{16}$ (19 examples), even if discret turns out to be more frequent (48 examples). As can be deduced from the lexical types, percepual accessibility embraces visual, auditory and tactile perception.

Importantly, color adjectives - and adjectives denoting a color in a figurative way - seem only to be possible. if they express a degree of visibility or luminosity ${ }^{17}$ rather than a color proper: noir ('black', heaven), pâle ('pale', light) and, with respect to the sea (due to the fading of the light), sombre (3; 'dark'), obscur ('obscure'), crépusculaire ('crepuscular') and gris ('grey'). Compare:

(32) Le ciel se fit noir.

'The sky turned black'

(33) *Le feu se fait vert. Les voitures peuvent passer

'The traffic light turns green. The cars can move on'.

(b) aspectuo-temporal adjectives expressing duration with a "negative impact" on the experiencer

Adjectives such as long ('long'), interminable ('endless'), éternel ('eternal') and court ('short') referring to the (subjective) experience of time are frequently attested in the Frantext corpus. It should be stressed that the experience of time is subjective in that there is no change of state affecting the referent itself. Crucially, se faire is strongly attracted by aspectual adjectives that imply a negative impact on the experiencer, whereas, positively-orientated adjectives turn out to be extremely marginal, to the extent that many natives reject them:

(34) (aux urgences) Arrivé la bas [sic] l'attente se fait courte on est prit [sic] en charge directement.

'As soon as we arrived there, the wait became short and care was immediately taken of us'

However, if court 'short' occurs in a context in which it has a negative impact on the experiencer, then se faire turns out to be very natural:

(35) La nuit se fit courte. C'est à grand-peine que nous nous levâmes.

'The night became short. It was only with great difficulty that we got up.'

In the same fashion, aspectual adjectives other than those expressing duration are possible if ${ }^{18}$ there is a negative effect on the experiencer:

(36) Les perquisitions se font incessantes.

'Searches become incessant'

(c) adjectives meaning 'difficult' or 'unbearable'

In fact, the second group of adjectives may be considered a subgroup of the third group, which represent no less than $17 \%$ of the Frantext examples (42 examples):

intenable ('unbearable'), intolérable ('intolerable'), blessant ('cutting'), oppressant ('oppressive'), fiévreux ('excited'), brûlant ('scorching'), prenant ('absorbing'), lourd ('heavy') (6), languissant ('flagging'), râpeux ('unpleasant [noice], something that disturbs the silence'), violent ('violent'), véhément ('vehement'), sanglant ('cruel'), insistant ('insistent'), invitant ('appealing'), vif ('vivid, tough [competition]'), difficile

\footnotetext{
${ }^{16}$ Limited to "se fait très".

${ }^{17} \mathrm{Cf}$. also the impersonal construction with weather elements: il se fait sombre 'it is getting dark'. Other adjectives are not allowed: *il se fait froid 'it is getting cold'.

${ }^{18}$ One counter-example has been found: la respiration se fait régulière 'the breathing becomes regular'.
} 
('difficult'), redoutable ('dreadful'), étouffant ('stifling'), épais ('stifling' [summer]'), pressant ('urgent'), anarchique ('anarchic'), dangereux ('dangerous'), grand ('strong, hard to resist' [temptation]), terrible ('terrible'), pathétique ('pathetic'), frénétique ('frenetic'), agissant ('active'), grossier ('coarse'), rageur ('angry, hard' [wind]), douleureux ('painful'), provocant ('provoking'), funèbre ('mournful'), lent/pénétrant ('slowly penetrating' [death]), tranchant ('sharp, peremptory' [observations]), sec/coupant ('curt, sharp').

These adjectives have in common that they affect the experiencer in a negative way to the extent that they refer to a difficult, unbearable state of affairs. Importantly, se faire does not combine with the autonyms of these adjectives. For instance, facile 'easy' and simple 'simple':

(37) La vie se fait difficile. vs. *La vie se fait facile ${ }^{19}$.

'Life becomes difficult' vs. 'Life becomes easy'.

(38) La marche se fait pénible vs *Ces choses se font simples.

'Walking becomes painful' vs. 'these things become simple'

Very often, se faire creates the impression of a crescendo, a negative spiral. In several examples the unbearable character of the described change of state takes on a sensory dimension: l'air se fait lourd ('the air gets heavy'), la chaleur se fait étouffante ('the heat becomes stifling'), ...

This intriguing propensity for 'negative' feelings may have something to do with a remnant of the initial agentive meaning of se faire: only phenomena that affect the experiencer in a 'negative' "impose" themselves on her/him.

(d) crescendo / high degree of salience

A fourth cluster of adjectives has to do with the expression of a high degree of salience (i) or a maximum degree of completion (ii):

(i) aigu ('sharp' [attention]), prépondérant ('preponderant' [role]), telle que + intensive ('such a $\mathrm{N}$ that' [fear]), central ('central' [facet])

E.g. Le rôle du conseil se fait prépondérant.

(ii) définitive ('for good' [separation]), totale ('total' [alienation]), éternel ('eternal'; [everything around you])), complet ('complete' [night]), ??intact ('intact' [bad luck]), complet ('complete' [obscurity]), absolu ('absolute' [thought]).

It must be observed that some of the examples are hardly acceptable nowadays.

\section{(e) deontic adjectives}

The next cluster of Frantext examples are deontic in nature: impérieux, urgent and impératif. All five examples are related to an internally experienced necessity, which is not imposed by an external organism, contrary to adjectives such as obligatoire 'obligatory', which cannot be combined with se faire:

(39) La guerre se fait inévitable.

'War becomes inevitable'

vs. (40) *La peine de mort se fait obligatoire.

'The death penalty becomes obligatory'.

Compared to devenir, se faire adds a particular nuance to the change of state. For instance, in la guerre se fait inévitable, the war plays a more «active » role than in the case of devient

\footnotetext{
19 The following example, found on the Internet, is not a true counter-example, since La descente se fait facile, je double d'autres coureurs et je finis seul la descente 'The descent becomes easy, I pass other skiers and I finish the descent on my own' (http://www.kikourou.net/recits/recit-2910-trail_nivolet-revard_-_49_km-2007-parstartijenn.html -- 14/05/2007) sounds not only very unnatural to natives, but, moreover, involves change through motion, since the position of the skier is constantly changing (cf. 4.3. infra).
} 
inévitable. As a result, se faire stresses the urgent, inevitable character of the state of affairs. In a sense, in the meaning of se faire we still find a remnant of its initial active meaning, as if something (the subject) were imposing itself (and not by means of an external organism).

\section{(f) adjectives that express something that impacts the experiencer}

Finally, the Frantext corpus contains 6 examples of adjectives expressing surprise: bizarre 'bizar', mystérieux 'mysterious', étrange 'strange', singulier 'singular'. The astonishment of the experiencer is often related to auditory or visual perception. Since 'becoming weird' comes very close to 'creating a weird impression' these adjectives constitute a natural bridging category between change occurring in real life and change at the level of subjective perception. Once more, se faire cannot be combined with the antonyms of these adjectives (which are equally evaluative): ${ }^{*} X$ se fait normal ' $\mathrm{X}$ becomes normal'.

The categories discussed so far summarize $67.8 \%$ of the instances of the structure inanimate subject + se faire + adjective found in the Frantext corpus $\left(20^{\text {th }}\right.$ century $)$. This percentage would have been substantially higher if we had included some of the remaining examples on the basis of an additional interpretive calculus. However, instead of getting involved in subtle stylistic analyses of (hardly acceptable) literary examples, we preferred to operate with rather straightforward categories ${ }^{20}$.

If we look at the more informal genres, we must conclude that the ongoing decline of se faire enhances the relevance of the central semantic categories. Our Google searches ("se fait très") show that only categories (a) and (b/c) remain relevant on the Internet.

\subsubsection{A 'subjective' change of state}

Let us now put these distributional observations in perspective. What do the observed semantic categories tell us about the meaning of se faire? What these adjectives have in common, is that they point towards a subjective perspectivation of the change of state, which is absent in the case of devenir. Subjectivity and subjectification are notions very much debated in the recent literature (Stein \& Wright eds, 2005; Athanasiadou et al. eds, 2006). By subjectification we mean that "meanings tend to become increasingly situated in the speaker's subjective belief state or attitude toward the proposition" (Traugott, 1989: 31). In this sense, subjectification corresponds to an enrichment of the meaning of a word by the speaker's perspective. It is a diachronic process, with synchronic layering as a result.

In the case of se faire, the adjectives acting as predicative complements clearly exhibit the involvement of a human experiencer or conceptualizer who views the scene, as it happens, the reported change of state. The conceptualizer is mostly left unexpressed (or, to use Langackers 1990 terminology, remains «off stage ») and most often corresponds to the speaker herself/himself. More specifically :

(i) the referent becomes more or less accessible (visible, audible, etc.) to the conceptualizer (but the referent as such does not undergo any change) [=a]

(ii) the referent is more and more needed, the need imposing itself on the conceptualizer $[=\mathrm{e}]$

(iii) the referent is considered more and more unbearable by the conceptualizer, it has a negative impact on the conceptualizer $[=\mathrm{b} ; \mathrm{c}]$

(iv) the referent appears as rather intriguing to the conceptualizer $[=\mathrm{f}]$

\footnotetext{
${ }^{20}$ Some of the more problematic cases include adjectives referring to "objective" properties though conceived metaphorically (e.g. la nuit se fait duveteuse 'The night becomes downy'), expressing very often an unpleasant feeling, e.g. le vent se fait dense et touffu ('the wind gets dense and bushy'). Further, some of the corpus examples involve personification, which means that their inanimate subjects function as if they were animate (and hence endowed with volition): les eaux se font accueillantes ('the waters become friendly').
} 
Crucially, change does not affect the referent itself, but rather the relation between the referent and the experiencer. For instance, being more or less visible is a property which quantifies human visual experience. In cases such as la saison se fait longue ("the season is getting long'), the subjective effect is very clear. What changes is not the football season as such, but rather the perception by the players of the team as they are getting tired. In other cases, subjectification manifests itself in a more subtle way, but still, quite often speakers feel a difference between se faire and devenir. For instance, certain speakers feel more involved when they say L'eau se fait rare ('Water is getting rare'). In Le brouillard se fait épais fog seems to be more palpable than in the case of devenir.

In all these cases, change has been put into a subjective perspective, which is the perspective of the experiencer or conceptualizer (very often the speaker). Graphically :

\section{Figure 1}

Interestingly, in some of the semantic categories discussed in 4.2.1., the original dynamic meaning of (se) faire as a verb of creation or transformation controlled by a human subject is still somehow present, albeit transposed onto a more abstract level of interpretation:

- a reality that manifests or retracts itself to the perception of the experiencer $[=\mathrm{a}]$, that strikes the experiencer $[=\mathrm{f}]$ or that has a high degree of salience $[=\mathrm{d}]$

- a necessity that imposes itself (not imposed by an institution) [=e]

$-\mathrm{a}$ referent that acts in such an intrusive way that it becomes unbearable $(=b, c)$

This causative effect might explain why people have the impression that se faire has a more "vivid" meaning than devenir (e.g. the need is felt to be more urgent, the fog more tangible, etc.).

The evolution of se faire clearly corresponds to subjectification as described in the work of Traugott (e.g. 1989). One notes a shift from a meaning based on the description of the external, objective world (as it happens, a change of state) to the subjective perception of a change of state, on the basis of a pragmatic implicature ${ }^{21}$ : objective change $>$ change in the eyes of / relevant to a conceptualizer. This is the first step in the subjectification process of se faire. The second step, from subjective change of state to a stative, evidential reading, strengthens the subjective attitude of the speaker (evidential inference). Let us us now turn our attention to this second step.

\subsection{Subjectivity and 'virtual' change of state}

Now that the meaning of dynamic se faire has been identified, it is easy to understand how this subjective meaning is giving rise to an evidential one. Our corpus examples of evidential se faire suggest that the subjective dimension has become so dominant that it has backgrounded the dynamic aspect (change of state). In that case, there is, objectively speaking, no change of state at all (cf. football season example). What really matters is the effect produced on an (« offstage ») conceptualizer :

\footnotetext{
${ }^{21}$ Admittedly, devenir can be used with a similar 'subjective' implicature ('become' $\rightarrow$ 'become in the eyes of the conceptualizer/speaker'). However, to trigger the same implicature, one must add adjuncts such as pour $X$, which somehow explicitate the experiencer: la saison devient longue (pour eux) 'The season is getting long (for them'. In other words, devenir is the default (and hence objective) marker of change of state in French and is, as such, underspecified with regard to subjectivity. Se faire, by contrast, inherently encodes a subjective meaning (which has been semanticized, after a process of pragmatic strengthning), as shown by the distributional tendencies and lexical restrictions on the predicative complement.
} 


\section{Figure 2}

Accordingly, se faire + adjective can be paraphrased by 'to look ADJ, to be ADJ, to produce a ADJ (perceptual) impression'.

The relevance of this subjectification path can be inferred from the fact that the adjectives occurring in an evidential reading appear to be closely associated with those found with a dynamic reading. Moreover, numerous bridging contexts are attested in the corpus (see 3.1.).

If we now subject this second step of the subjectification process to further scrutiny, it appears that the gradual shift from 'subjective change' toward 'absence of change' has been favored by a conceptual mechanism that very often has been discussed in relation with motion verbs: fictive (virtual or subjective) motion (a.o. Langacker, 1986; Matsumoto, 1996; Talmy, 1996). In

(41) This fence goes from the plateau to the valley (Talmy, 1996: 99)

The fence does not change its position from the plateau to the valley. Rather, a conceptualizer - who is off stage - mentally "follows" or "scans" the trajectory of the fence. In this sense, motion is only "virtual", "fictive" or "subjective" and is used to conceptualize a stative state of affairs in a more lively way. According to Langacker, subjective (or fictive) motion is therefore a case of subjectification, as is the fictive motion involved in the aspectual periphrastic use of be going to (Langacker, 1990: 23-25).

Something similar to subjective motion is happening with se faire. Let us consider some Google instances:

(42) Plus nous marchons, moins Paris ressemble à lui-même; les maisons se font petites, les horizons se font larges. Ce n'est déjà plus la grande ville (books.google.be/books?isbn=0543920283)

'As we go further, Paris resembles itself less and less; houses are getting smaller, while horizons are getting larger. The big city is already far away'.

Example (42) documents a first step in the process leading to virtual change. There is real motion, but the change of state it triggers cannot be considered a 'real' change of state, since the change in dimension of the houses is only possible because it is triggered by the changing position (= still 'real' motion) of the experiencer. Moreover, the change does not affect one particular, stable object: the houses at point A are not the same as the houses at point B. In this case, two different referents are compared, rather than two 'stages' of one single referent. In (43), although still present, motion tends to be virtual or mental: when mentally walking along the river, the river becomes wider (compared to other stretches previously passed by $)^{22}$ :

(43) [reporting a walk] Nous terminons l'itinéraire sur le pont qui enjambe la Meuse. A cet endroit, elle se fait large et majestueuse. (www.tripy.eu/roadBookDetails.asp?...943)

'We end our outing on the bridge over the Meuse [= river]. There it looks large and majestic'

Both the context (l'itinéraire) and our world knowledge make it possible to integrate the described scene within a (fictive / virtual) temporal development in which change can occur. The examples (42) and (43) show, thus, an evolution towards a static meaning, involving no change of state at all. It is however possible to recognize in these examples the construction of a 'fictitious' change of state (through time), due to the changing position of the experiencer either physically or mentally).

\footnotetext{
${ }^{22}$ This example is very similar to The road widens there. Virtual motion and virtual change are combined when "a moving perspective is taken, and the change is noted as the focus of attention moves" (Matsumoto 1996: 140). In other words, "the subjective change [is] triggered by subjective motion" (Matsumoto 1996: 141). See also Talmy (2000: 170) who comments on examples such as The soil reddens toward the east.
} 
Admittedly, in both examples virtual change is triggered by (real / virtual) motion in space, which make them very interesting bridging contexts between dynamic and stative se faire. By contrast, in the next example, there is no motion in space whatsoever, except virtual motion:

(44) Autour de ton église nichées / Les maisons se font petites (http://tachka.over-blog.com/)

'Centred around your church / the houses look small'

(44) illustrates a more abstract realization of virtual motion involving an implicit comparison based on mental scanning along the skyline: starting from the church, the houses built around the church "become" small. This example illustrates quite well the implicit comparison involved in what has been called "subjective" or "virtual" change (Matsumoto, 1996: 150; Langacker, 1999a: 85; Brandt, 2009: 13). In virtual change, change is "invoked to contrast the profiled configuration with the canonical one" (Langacker, 1999a: 85). However, in our examples the reference state can be a property of another referent to which a current state of affairs is compared (e.g. church - houses; houses downtown Paris $v s$. in the periphery; etc.). It is not necessarily a "normative" benchmark.

Up to now, we have argued that virtual change is crucial to better understand the relation between dynamic se faire and evidential se faire, and that it is often related to motion $(42,43)$ or virtual motion (44), in that by mentally changing the position of the observer over time, some temporal development can be construed wherein (subjective) change can occur. The link between motion and change of state does not come as a surprise, of course, since copular verbs (de-venir 'become', rester 'stay/remain', passer 'become ( $<$ pass)'; Dutch raken 'become (<reach)' and aspectual semi-auxiliaries (venir de 'just + inf.' [< come from], aller 'go', is going to, etc.) expressing change of state can often be considered metaphorical extensions of motion verbs (change of position $\rightarrow$ change of state).

Given the tight relationship between virtual change and virtual motion, it is quite normal that verbs based on virtual change (fashion changes over time) can co-occur with verbs expressing virtual motion (clothes are described as if they were moving along the body):

(45) <description of a new collection along the catwalk> Les jupes se font amples et restent sagement à mimollet, tandis que blouses et pulls montent jusqu'au coup [sic pro cou] dans une volonté affichée de sublimer le corps non pas par l'abondance de chair nue mais par le biais de la suggestivité. (http://www.avmaroc.com/pdf/mode-milan-actualite-a121544-d.pdf)

'Skirts \{become / look\} full and stay wisely halfway down the calf, while blouses and pullovers come up to the neck, showing the clear will to sublimate the body not by an abundance of naked flesh but by suggestiveness'

Fictive motion and fictive change of state go often hand in hand.

Of course, se faire as such is not a motion verb and fictive change of state does not always entail (fictive) motion in space. Rather, what is really crucial to explain the shift from dynamic to stative in the case of se faire, is the possibility to construe an event which sets up a time frame in which the conceptualizer can (fictively) experience a change of state. This event is very often contextually present. For instance, in (46), reference is made to a particular step (au goût) during beer tasting, but there is no change of state anymore (as shown by the impossibility of replacing se faire by devenir):

- during a wine/beer-tasting :

(46) Au goût, le miel se fait discret, ne laissant pas de sucré trop écoeurant. [= when it comes to tasting, id est after having smelt the aroma of the beer]

'As to taste, the honey comes through very discreetly, without leaving behind a too-disgusting sugar taste'.

(http://bieresbelges.skynetblogs.be/archive-week/2005-03; 15/5/2010)

- a car test : 
(47) la MX-5 affiche une bonne stabilité à haute vitesse mais se fait très bruyante. (auto.orange.fr/.../essais_mazda_mx-5_ADMN-6JVKNV.html)

'the MX-5 is quite stable at high speed but appears to be very noisy'

- when taking a cell phone at hand, one is progressively experiencing a change in his beliefs: cf. (16).

What really seems to matter, is the creation of a «fictive temporal development » within a (objectively) 'stative' state of affairs. This fictive temporal development can in some cases be sustained by (fictive) motion (as motion takes time), but not necessarily.

Finally, there are also examples in which no such global event can be reconstructed:

(48) [video game] L'arsenal de Gears of War se fait très varié.

'The arsenal of Gears of War looks very varied' (http://emergenceday.blog.jeuxvideo.com/r42148/Armes/)

This example shows that the evidential meaning forms already part of the meaning of se faire; it appears even when contextually triggered cognitive mechanism are absent. In this respect, se faire differs from devenir. Devenir can be used in the framework of virtual change, but only to a certain extent and only if contextual clues are present. For instance, (43) is perfectly acceptable with devenir:

(43') [reporting a walk] Nous terminons l'itinéraire sur le pont qui enjambe la Meuse. A cet endroit, elle devient large et majestueuse.

By contrasts, examples (44, 47, 48 and 16) show that se faire has gone beyond the (bridging) mechanism of virtual change; it has become an evidential verb.

In sum, the mechanism of virtual change - which is quite similar to that of virtual motion seems to be a crucial factor in the shift from (subjective) aspectual meaning to evidentiality ${ }^{23}$, which completes the subjective turn in the history of se faire. The following subjectification path can be proposed :

$$
\begin{array}{lll} 
& \text { first step } & \text { second step } \\
\text { dynamic; non subjective } \quad>\quad \text { dynamic; subjective } \quad>\quad \text { non-dynamic; subjective }
\end{array}
$$

As to the second step, we have argued that virtual change seems to be on the basis of the evolution towards an evidential meaning. From the point of view of the theory of virtual motion and virtual change (e.g. Brandt 2009), the case of se faire is interesting, as it shows that virtual change is possible without virtual motion and that this mechanism can be an important factor in the development of evidential usages from aspectual change of state meanings. Moreover, the development of evidential usages of se faire is very recent, which means that the ultimate stage can be perceived at its incipient stage. As a consequence, the evidential reading is only available (or acceptable) with certain lexical items related to the category of sensory perception (cf. 3.1.). By contrast, attested examples involving other adjectives are most often rejected by native speakers. On the whole, the rise of evidential meanings completes the process of deagentivization ${ }^{24}$ by adding a new layer (layering, Hopper 1991) to the semantics of the construction of se faire with a predicative complement.

\footnotetext{
${ }^{23}$ It should be noted that the development of evidential readings may also have been favored by the very frequent use of se faire with human subjects expressing a controlled but non intrinsic (temporary) change of state (see 2.1.2.). For instance, il se fit agressif means 'he adopts an aggressive posture, but he is not like that intrinsically'. This paraphrase suggest that there is no 'real' change of state at play. What matters is the "impression" produced, the appearance, which may have favoured the evidential use of se faire with subjects that do not allow for control. This explanation is however less convincing because of the factive orientation of evidential se faire, which, indeed, is never contradictable (cf. supra 3.2.).

${ }^{24}$ It must be recalled that alongside this evolution the corresponding transitive construction has steadily disappeared and been replaced by rendre.
} 


\section{Hacerse: confirmation}

The rather intringuing subjectification path of se faire, which leads from aspect to evidentiality, has been confirmed by the analysis of its Spanish cognate hacerse ('become'). Apart from some minor usages, the distributional scope of hacerse + adjective is much larger than that of se faire. On the other hand, hacerse + adjective appears to be more restricted than devenir, because of its paradigmatic position. As is well known, unlike French, Spanish has no generic change of state copula. Instead, it possesses a series of aspectual variants (hacerse, volverse, ponerse, etc.) (Porroche, 1990 ; Bybee \& Eddington, 2006).
(49) le film se fait long
se hace larga
le film devient long (pour X)
'the film is getting long'
(50) *la rivière se fait profonde
el río se hace profundo
la rivière devient profonde
'the river is getting deep'
(51) *Pierre se fait fou
*Pedro se hace loco (> se vuelve loco) Pierre devient fou

'Pierre is going crazy'

As to the distribution of hacerse, we cannot investigate all the details here. We will limit ourselves to some observations that confirm the subjectification path going from aspect to evidentiality. Indeed, like se faire, hacerse can express a purely evidential meaning without any change of state involved:

(52) Deltia, el termostato, se hace discreto y elegante.

(www.teknoimport.cl/Archivos_PDf/DELTA.../Deltia.pdf; this webpage does not exist anymore)

'Deltia, the thermostat, looks discreet and elegant'

(53) También en Latinoamérica su influencia se hace evidente. (Davies corpus)

'In Latin America too his influence is clear'

(54) La nómina de partícipes se hace variada. (Davies corpus)

'The list of participants appears varied'.

Unlike evidential se faire, however, evidential hacerse is massively attested in literary and journalistic corpora. While Frantext does not provide any example of evidential se faire, the Davies corpus contains 79 unambigous examples of evidential hacerse (involving no temporal development at all), corresponding to about 20 per cent of the instances of hacerse + adjective. Besides those 79 examples, many ambiguous bridging contexts have been found in which one could still recognize a change of state in one way or another. Moreover, the adjectives involved cover a larger array of semantic fields (extensible 'extendible', fluido 'fluid', independiente 'independent', singular 'singular', variado 'varied', ...), which are either impossible or very difficult to translate in French by se faire:

(55) no se me hace bueno que cortaras mis creditos, pero tu sabras.

(www.youtube.com/watch?v=UCWbbevpyTc\&feature=related; this page has disappeared from the web)

'it doesn't seem right to me that you refuse me credit, but I suppose you know.'

(56) El análisis de la C10 [...] se hace complejo.

(horoscopia.venezuela.com/Peru\%20jura\%20Garcial\%20julio\%202006.html)

'The analysis of the $\mathrm{C} 10[\ldots]$ looks complex'

Instead, French uses other copular verbs such as sembler and paraître.

Nevertheless, the central semantic clusters of evidential hacerse correspond to those of evidential and aspectual se faire, which suggest that a similar evolution has occurred in Spanish:

- Perception (+ epistemic): aparente 'apparent', asequible 'accessible, afordable', evidente 'evident' (13 examples!), indiscutible 'inconstestable', indudable 'indubitable', inverosimil 'incredible', manifiesto 'clear', notorio '(well-)known' 
- Deontic: aconsejable 'advisable', fundamental 'fundamental', imperioso 'urgent', importante 'important', imprescindible 'indispensible', inevitable 'inevitable', (in)necesario 'unnecessary' (22 examples), pertinente 'relevant', preciso 'important', urgente 'urgent', forzoso 'necessary'

- 'unbearable': abrumador 'overwhelming', difícil 'difficult' (13 examples), impenetrable 'impenetrable', interminable 'endless', largo 'long', inminente 'imminent'

Remarkably, spoken (Mexican) Spanish even seems to allow animate subjects in an evidential reading :

(57) Y a ti se te hacen buenos los mexicanos? (Habla Culta: Mexico: M31; Davies)

'And do they seem fine to you, the Mexicans?'

These synchronic observations suggest that Spanish hacerse

(i) has undergone a similar evolution

(ii) appears to be more « evolved » than its French counterpart (since wilful subjects can be forced into a stative evidential reading, although only in a spoken variant).

As to meaning, evidential hacerse comes close to the meaning of se faire, although quite often hacerse means 'to seem ADJ':

(58) Tras una espera no muy larga pero que a ella se le hacía interminable, aparecía él. (Davies corpus)

'After a short wait, which seemed endless to her, he showed up'

(59) Las calles se le hicieron misteriosas y el edificio del Multifamiliar le pareció de pronto oscuro.

(Davies corpus)

'The streets seemed mysterious to him and the building of the Multifamiliar suddenly seemed obscure to him'

(60) A mí se me hacía raro oírle a la Postiza llamarle por su nombre. (Davies corpus)

'It felt strange to me to hear la Postiza call her by her name'

The interpretation of hacerse as a verb of appearance - as suggested by contextual elements such as no muy larga 'not too long' and pareció 'seemed' - is hardly inevitable if the verb is accompanied by a dative (which is not available with se faire). This interpretation also corresponds to the paraphrase provided in the work of Porroche (1990: 116): 'me ha parecido' ('it seemed to me'). The dative, however, must not be necessarily present to obtain this meaning effect:

(61) El trayecto por los subterráneos no se hizo largo porque la visión de los tesoros desató la lengua de Balbina (Davies corpus)

'The route passing through the tunnels did not seem long because seeing the treasures loosened her tongue'

$=$ Le trajet ne parut pas long; *ne se faisait pas long

Let us visualize the position of both verbs on a gradient :

\section{Table 4}

In other words, the meaning of hacerse is more remote from ser 'be' than se faire from être 'be' and resembles more the meaning of parecer. However, hacerse does not correspond exactly to the meaning of parecer 'seem' (appearance) ${ }^{25}$.

Similarly, from the point of view of syntactic construction, hacerse behaves more like the family of 'seem' verbs than se faire. Indeed, hacerse allows two constructions typical of evidential copulas expressing 'appearance', which suggests that this verb is better integrated in the paradigm of epistemic copular verbs:

(i) the (optional) dative construction, explicating the experiencer ${ }^{26}$ (cf. examples supra)

\footnotetext{
${ }^{25}$ On the other side of the spectrum, Spanish does not have a counterfactually oriented verb like faire + adjective (e.g. il fait vieux 'he seems old, but actually he isn't').
} 
(ii) the impersonal construction combined with infinitives and complement clauses:

(61) se hace necesario que profesionales de todos los ámbitos tengan una formación completa (www.emagister.com.co/como-se-hace-tps-4748.htm)

'[it] seems/is necessary that professionals in all areas receive a complete education'

(62) En la actualidad se hace necesario incorporar los puertos a las redes de transporte (www.voyagesphotosmanu.com/puertos_argentinos.html)

'Nowadays [it] seems/is necessary to integrate the harbours into the transport networks'

If one wants to translate these sentences into French, only a translation by il me semble ADJ or il est ADJ ... de / que is possible.

Although both se faire and hacerse display a similar layering combining aspectual and evidential usages, the diachronic evolution of both verbs is not identical. For instance, the evidential construction with the dative has been attested at least since the $15^{\text {th }}$ century (Davies corpus):

(62) porque al grande coraçon animoso: todo le pareçe poco: todo se le faze ligero (Crónica de Aragon; 1499; Davies corpus)

'because to the brave great heart: everything seems little ['weinig'] to it: everything seems light ['licht']'

(63) una vez se me hazia estraño su parecer otra vez me parecia como que le conocia sin poder le conocer (Cancionero Juan del Encina; 1496; Davies corpus).

'sometimes his appearance seemed strange to me; sometimes it seemed as if I knew him without being able to know him'

The question whether similar mechanisms leading from aspect to evidentiality have been at work in the history of hacerse can only be traced back by a detailed diachronic study which exceeds the scope of this paper. But it seems very plausible that the dative has facilitated the development of evidential readings (cf. Gisborne \& Holmes, 2007), something which has not been possible in the case of se faire.

\section{Conclusions}

In this paper, we have shown that se faire has become a (semi-)copular verb endowed with both an aspectual and - only very recently - evidential meaning. This evidential meaning relies on an inferential calculus based on evidence, but has little to do with appearance, which makes se faire rather different from sembler and paraitre. This difference in meaning is also reflected in the absence of the dative and the infinitive/complement clause construction. By contrast, both constructions are available for hacerse.

The case of se faire is only one example of the lexicalization of reflexive constructions followed by a predicative complement yielding new copular verbs. Other cases in point are $s e$ révéler 'turn out to be', s'avérer 'turn out to be', s'annoncer 'will certainly be', se sentir 'feel ADJ', etc. Most of them have developed evidential or modal meanings. The outcome of these evolutions is multi-layered verbs, or, more precisely, multi-layered, polysemic verb constructions, since se faire has also other, non-copular constructions.

The case of se faire is, however, a very interesting one. Not only because of the particular evidential meaning effect, but also because of the original subjectification path it illustrates. This subjectification path, which leads from aspect (change of state) to evidentiality, has been confirmed by the global evolution of Sp. hacerse, although diachronical details may differ. Of course, shifts from aspect to modality are not exceptional. For instance, in Sp. resultar, which can be used both as a copular verb and a semi-auxiliary, the resultative meaning has been backgrounded in favor of an evidential reading. But among the «evidential strategies »

\footnotetext{
${ }^{26}$ Note that the dative does not preclude a dynamic interpretation: La carretera se le hizo visible 'the road became visible to him' (Camacho, El Adobe, corpus Davies). One third - 10 out of 32 - of the examples with a dative in the Davies corpus $\left(20^{\text {th }}\right.$ century) are stative in nature.
} 
mentioned in Aikhenvaldt (2006), we did not find any subjectification path corresponding to that illustrated by se faire / hacerse, which involves a shift from dynamic aspect (change of state) - as opposed to resultative aspect (e.g. in Bybee, Perkins \& Pagliuca, 1994: 95-97) ${ }^{27}$ to evidentiality. Moreover, the rise of a stative, evidential meaning that accompanies the bleaching of a verb expressing originally a (controlled) change of state, illustrates an interesting case of a cognitively-driven grammaticalization process involving subjective perspectivation of change, followed by a mechanism analogous to virtual motion, namely virtual change (of state). In a sense, the subjectification process of se faire illustrates how compatible Traugott's and Langacker's views on subjectification can be (Athanasiadou et al. eds, 2006).

Considering the multi-layered lexeme se faire from a macro-semantic point of view, one might advance the hypothesis that the causative meaning ("to do something in order to transform something') is still somehow present in the present-day uses of se faire. This is very obvious in the marginal reflexive uses with human subjects (elle se fait belle 'she makes herself beautiful'), which still allow for subject control. More interestingly, as we have argued, it is also present, albeit in a very latent way, in the intransitive uses of se faire as a change of state verb without subject control (4.2.2.). As a consequence, se faire encodes a more "lively" construal of the (subjectified) change of state than devenir. This latent meaning effect also shows through the evidential use of se faire ('something shows itself to be ADJ'). In this respect, it should be recalled that the creation of a (sensory) impression is a crucial element in the meaning of the non-reflexive copular use of faire (ce vin fait très jeune lit. this wine smells very young, 'seems to be very young'; Lauwers, 2008). These subtle nuances may be considered symptoms of « lexical persistence» (Hopper, 1991), in which the original causative element has been transposed on to a very abstract level.

\section{Acknowledgements}

We would like to thank several people with whom we have discussed the topic of this paper, especially M.Achard, P.Marlet, E.Tobback, D.Apothéloz, M.Nowakowska, G.de SaintMoulin, D.Bottineau and the anonymous reviewers of Journal of Pragmatics. Many thanks also to P.Hewins for correcting our English. Of course, all remaining errors are our own.

\section{References}

Aikhenvald, Alexandra, 2006. Evidentiality. Oxford: Oxford University Press.

Athanasiadou, Angeliki, Canakis Costas, Cornillie Bert (eds), 2006. Subjectification: Various paths to Subjectivity. Mouton de Gruyter, Berlin - New York.

Brandt, Line, 2009. Subjectivity in the act of representing: The case for subjective motion and change. Phenomenology and the Cognitive Sciences. [Online publication. www.springerlink.com/index/f7h1125u75537024.pdf].

Bybee, Joan, Revere Perkins, William Pagliuca, 1994. The evolution of grammar: Tense, aspect, and modality in the languages of the world. The University of Chicago Press, Chicago \& London.

\footnotetext{
${ }^{27}$ Past action inferred from present results.
} 
Bybee, Joan, Eddington, David, 2006. A usage-based approach to Spanish verbs of 'becoming.' Language 82 (2), 323-355.

Chafe, Wallace L., 1986. Evidentiality in English Conversation and Academic Writing. In: Chafe, W.L., Nichols, J. (eds), Evidentiality: the Linguistic Coding of Epistemology. Ablex Publishing Corporation, Norwood, New Jersey.

Cornillie, Bert, 2004. The shift from lexical to subjective readings of Spanish prometer 'to promise' and amenazar 'to threaten'. A corpus-based account. Pragmatics14 (1), 1-30.

Cornillie, Bert, 2004. Evidentiality and epistemic modality in Spanish (semi-)auxiliaries. A functional-pragmatic and cognitive-linguistic account. Leuven: PhD thesis.

Cornillie, Bert, 2007. Epistemic Modality and Evidentiality in Spanish (semi-)auxiliaries. A Cognitive-functional Approach. Mouton de Gruyter, Berlin/New York.

Cornillie, Bert, 2009. Evidentiality and epistemic modality: on the close relationship of two different categories. Functions of Language 16 (1), 44-32.

De Haan, Ferdinand, 2001. The Relation between modality and evidentiality. Linguistische Berichte, Sonderheft 9, pp. 201-216.

Delplanque, Alain, 2006. Juger d'après les apparences: le cas du français. Corela. Numéro spécial: Les verbes d'apparence.

[e-journal : http://edel.univ-poitiers.fr/corela/document.php?id=838]

Dendale, Patrick, Tasmowski, Liliane, 2001. Introduction: evidentiality and related notions. Journal of pragmatics 33 (3), 339-348.

Diewald, Gabriele, 2002. A model for relevant types of contexts in grammaticalization. In Wischer, I., Diewald, G. (eds.), New reflections on grammaticalization, Benjamins, Amsterdam/Philadelphia, pp. 103-20.

Eddington, David, 1999. On 'becoming' in Spanish: A corpus analysis of verbs expressing change of state. [Unpublished manuscript http://linguistics.byu.edu/faculty/eddingtond/become.html]

Ekberg, Lena, Paradis, Carita, 2009. Evidentiality in language and cognition. Functions of Language 16, 5-7.

Gisborne, Nikolas, 2000. The complementation of verbs of appearance by adverbs. In: R. Bermudez-Otero, D. Denison, R. Hogg, C. McCully eds., Generative theory and corpus study. Mouton, Berlin and New York, pp. 53-75.

Gisborne, Nikolas, Holmes, Jasper, 2007. The history of English evidential verbs of appearance. English Language and Linguistics 11/1, 1-29.

Grevisse, Maurice, Goosse, André, 1993. Le Bon Usage, De Boeck/Duculot, Louvain-laNeuve.

Hassler, Gerda, 2002. Evidentiality and reported speech in Romance languages. In: T. Güldemann, M. von Roncador (eds), Reported Discourse. A meeting ground for different linguistic domains. Benjamins, Amsterdam/Philadelphia, pp. 143-172.

Hengeveld, Kees, 1992. Non-verbal predication: Theory, Typology, Diachrony. Mouton de Gruyter, Berlin \& New York.

Hopper, Paul, Closs Traugott, Elisabeth, 1993. Grammaticalization. Cambridge University Press, Cambridge.

Lamiroy, Béatrice, Melis, Ludo, 2005. Les copules ressemblent-elles aux auxiliaires?. In: BatZeev Shyldkrot, H, Le Querler, N. (eds.), Les périphrases verbales. Benjamins, Amsterdam, pp.145-170.

Langacker, Ronald W., 1986. Abstract motion. Proceedings of the Annual Meeting of the Berkeley Linguistic Society 12, 455-471.

Langacker, Ronald W., 1990. Subjectification. Cognitive Linguistics 1, 5-38.

Langacker, Ronald W., 1999a. Virtual Reality. Studies in the Linguistic Sciences 29 (2), 77103. 
Langacker, Ronald W., 1999b. Losing Control: Grammaticization, Subjectification, and Transparency. In: Blank, A. and Koch, P. (eds.), Historical Semantics and Cognition, 147-175. Mouton de Gruyter, Berlin / New York, 147-175.

Langacker, Ronald W., 2006. Subjectification, grammaticization and conceptual archetypes. In: Athanasiadou, A, Canakis C., Cornillie, B. (eds), Subjectification: Various paths to Subjectivity, Mouton de Gruyter, Berlin/New York, 17-40.

Lauwers, Peter, 2007. Les noms nus inanimés attributs. Essai de classification syntaxique et sémantique. Journal of French Language Studies 17 (1), 151-171.

Lauwers, Peter, 2008. Les emplois attributifs de faire. Studia Neophilologica 80, 43-64.

Hopper, Paul J., 1991. On some principles of grammaticization. In Traugott, E. Closs \& Heine, B. (eds.), Approaches to grammaticalization, vol. 1: Focus on theoretical and methodological issues. Benjamins,Amsterdam/Philadelphia, pp. 17-35.

Matsumoto, Yo, 1996. Subjective-change expressions in Japanese and their cognitive and linguistic bases. In: Fauconnier, G., Sweetser, E. (eds.), Spaces, worlds, and grammar. University of Chicago Press, Chicago, pp. 124-156.

Miller, Philip, 2009. Prédication et évidentialité: de l'emploi copule des verbes de perception en anglais. Faits de langue 31/32.

Porroche Ballesteros, Margarita, 1990. Aspectos de la atribución en español. Libros Pórtico, Zaragoza.

Ruwet, Nicolas, 1972. Théorie syntaxique et syntaxe du français. Editions du Seuil, Paris.

Seuren, Pieter, 2003 Verb clusters and branching directionality in German and Dutch. In: Pieter AM Seuren, Kempen, G. (eds), Verb Constructions in German and Dutch, Benjamins, Amsterdam/New York, pp. 247-296.

Stein, Dieter, Wright, Susan, (eds) 1995. Subjectivity and Subjectivisation: Linguistic Perspectives, Cambridge University Press, Cambridge.

Talmy, Leonard, 1996. Fictive motion in language and 'ception'. In: Bloom, P. et al. (eds.), Language and Space, MIT Press, Bradford, pp. 211-276.

Talmy, Leonard, 2000. Toward a cognitive semantics, Volume 1. MIT Press, Cambridge, MA.

Tasmowski, Liliane, 1989. A look at sembler + infinitive from different angles. In: Jaspers, D. et al. (eds), Sentential Complementation and the Lexicon, Foris, Dordrecht/Providence, pp. 403-421.

Traugott, Elisabeth Closs, 1989. On the rise of epistemic meanings in English: An example of subjectification in semantic change. Language 65, 31-55.

Verhagen, Ari, 2000. The girl that promised to become something: An exploration into diachronic subjectification in Dutch. In:. Shannon, T.F. \& Snapper, J.P. (eds.), The Berkeley Conference on Dutch Linguistics 1997: The Dutch Language at the Millennium. University Press of America, Lanham, MD, pp. 197-208.

Willet, Thomas, 1988. A Cross-Linguistic Survey of the Grammaticization of Evidentiality. Studies in Language 12, 51-97.

\section{Corpora}

ADESSE. Base de datos de Verbos, Alternancias de Diátesis y Esquemas SintácticoSemánticos del Español. Available online at http://webs.uvigo.es/adesse/ 
C-ORAL-ROM. Cresti, Emmanuela, Moneglia, Massimo, eds 2005. C-ORAL-ROM. Integrated Reference Corpora for Spoken Romance Languages. Amsterdam / Philadelphia: Benjamins. [DVD]

Davies, Mark, 2002-. Corpus del Español (100 million words, 1200s-1900s). Available online at http://www.corpusdelespanol.org.

Frantext. Available online at http://www.frantext.fr/

\section{Bio-note}

PETER LAUWERS studied Romance Languages at the University of Leuven, with a specialization in French linguistics. After obtaining his MA in 1996, he worked as a research fellow of the National Fund of Scientific Research in Leuven, where he completed his Ph.D. in 2001. Since 2007, he has tenured part-time appointments at the Universities of Ghent and Leuven as an assistant professor of French linguistics.

His recent research, which benefitted from research stays in Strasbourg, Paris and Austin (Texas), is mainly concerned with two research lines: copular verbs and constructions, and issues related to linguistic categories and categorial 'mismatch'.

Claude DuÉE studied Spanish at the University of Toulouse-le-Mirail (branch of Madrid) and obtained her $\mathrm{PhD}$ in 1996 at the University of Caen with a thesis on the poems and writings of Gustavo Adolfo Bécquer, considered from a stylistic and psycho-analytic perspective. In 1999 she obtained an MA in French as a Foreign Language at the University of Grenoble. Between 1993 and 1996 she worked at the French Institute in Madrid. Since 1996 she is an associate professor at the French Department of the University of Castilla-La Mancha (Ciudad Real, Spain).

In the last few years her research interests were mainly concerned with reflexive constructions in French and Spanish.

\begin{tabular}{|c|c|c|c|}
\hline Frantext, 20 ${ }^{\text {th }}$ Century & & SUBCATEGORIES & TOTAL \\
\hline \multirow[t]{2}{*}{ Control, dynamic } & $\begin{array}{l}\text { Control, dynamic, reflexive, } \\
\text { non intrinsic } \\
\text { [animate] }\end{array}$ & $\begin{array}{l}\text { - Adjectives: } 24[=2.5 \%] \\
\text { - Nouns: } 133[=13.9 \%]\end{array}$ & $157[=16.4 \%]$ \\
\hline & $\begin{array}{l}\text { Control, dynamic, non } \\
\text { reflexive, non intrinsic } \\
\text { [animate] }\end{array}$ & $\begin{array}{l}\text { - Adjectives : } 55+103=158 \\
{[=16.5 \%]} \\
- \text { SN: } 103[=10.8 \%]\end{array}$ & $261[=27.3 \%]$ \\
\hline No control, dynamic & & $\begin{array}{l}\text { - Adjectives } \\
\quad-\text { animate : } 34+2=36 \\
{[=3.8 \%]} \\
\quad-\text { inanimate: } 340[=35.6 \\
\%] \\
\text { - Bare (inanimate) nouns: } \\
\text { 136 }[=14.2 \%] \\
\text {-SN: } 6[=0.6 \%]\end{array}$ & $518[=54.2 \%]$ \\
\hline $\begin{array}{l}\text { Non-dynamic } \\
\text { (evidential) }\end{array}$ & & & $0[=0 \%]$ \\
\hline Other $^{28}$ & & & $19[=1.99 \%]$ \\
\hline
\end{tabular}

\footnotetext{
${ }^{28} 15$ examples of se faire + adjective attest intrinsic change, but six of them have been found unacceptable by our native speakers and six others are hardly interpretable because they belong to philosophical discourse. The three remaining examples concern se faire pauvre ('to make oneself poor'). It is not entirely clear whether poor is really an example of intrinsic change : a (intrinsically) rich person is willing to live (in other words 'to
} 


\section{Table 5}

\begin{tabular}{|c|c|c|c|}
\hline \multicolumn{4}{|c|}{ factive } \\
\hline $\begin{array}{l}\text { être } \\
\text { 'be' }\end{array}$ & $\begin{array}{l}\text { se faire } \\
\text { 'appear as' }\end{array}$ & $\begin{array}{c}\text { sembler / paraître } \\
\text { 'seem' }\end{array}$ & $\begin{array}{l}\text { faire } \\
\text { 'look' }\end{array}$ \\
\hline
\end{tabular}

Table 6

\begin{tabular}{|c|c|c|c|c|c|}
\hline & $\begin{array}{l}\text { fq per million words } \\
\text { (absolute frequency) }\end{array}$ & $\begin{array}{c}\text { animate } \\
\text { (subject / [predicative } \\
\text { complement]) }\end{array}$ & $\begin{array}{c}\text { inanimate } \\
\text { (subject / [predicative } \\
\text { complement]) }\end{array}$ & $\begin{array}{c}\text { mixed } \\
\text { (animate } \\
\text { subject }+ \\
\text { inanimate PC } \\
+ \text { vice versa) }\end{array}$ & \\
\hline \multirow[t]{2}{*}{ Adj } & \multirow[t]{2}{*}{7,45 (577) } & $3.06(237)$ & $\begin{array}{l}4.39(340) \\
92(1.19) \text { of which are } \\
\text { related to animacy }\end{array}$ & - & \\
\hline & & $41.1 \%$ & $58.9 \%$ & - & $100 \%$ \\
\hline \multirow[t]{2}{*}{$\mathbf{N}$} & \multirow[t]{2}{*}{3,79 (293) } & $1.71(133)$ & $1.76(136)$ & $0.31(24)$ & \\
\hline & & $45.4 \%$ & $46.4 \%$ & $8.2 \%$ & $100 \%$ \\
\hline \multirow[t]{2}{*}{ Definite NP } & \multirow[t]{2}{*}{$1,70(132)$} & 103 & 6 & $23^{29}$ & \\
\hline & & $78 \%$ & $4.5 \%$ & $1.7 \%$ & $100 \%$ \\
\hline \multirow{2}{*}{$\begin{array}{l}\text { Indefinite } \\
\text { NP }\end{array}$} & \multirow[t]{2}{*}{$0(0)$} & - & - & - & \\
\hline & & & & & $100 \%$ \\
\hline TOTAL & $12,94(1002)$ & \multicolumn{4}{|c|}{$\begin{array}{l}\text { First half } 20^{\text {th }} \text { Century : } 14.26 \\
\text { Second half } 20^{\text {th }} \text { Century }: 11.02\end{array}$} \\
\hline
\end{tabular}

Table 7: se faire + predicative complement (Frantext)

\begin{tabular}{|c|l|l|l|l|}
\hline$<1600$ & $8.28(49)$ & $6.76(40)$ & $1.18(7)$ & $0.34(2)$ \\
\hline $1830-1850$ & $6.2(124)$ & $3.9(79)$ & $\begin{array}{l}2.22(45,8 \text { of which } \\
\text { related to animacy) }\end{array}$ & \\
\hline
\end{tabular}

Table 8: adjectival predicative complements (Frantext)

\begin{tabular}{|c|c|c|c|}
\hline factive --- sembler / paraître & Faire \\
\hline Etre & se faire & + datif & Parecer \\
\hline Ser & Hacerse & counterfactual \\
\hline
\end{tabular}

\section{Table 9}

behave') as a poor one. Finally, four examples have been found of the fixed expression se faire fort $(e) \operatorname{de}+$ inf. 'to be convinced of'.

${ }^{29} 16$ of which concern examples with the lexicalized expression se faire l'écho (lit. to make oneself the echo of, 'to diffuse'). 


\section{FIGURE 1}

devenir

[- ADJ] -temporal development [+ ADJ]

se faire

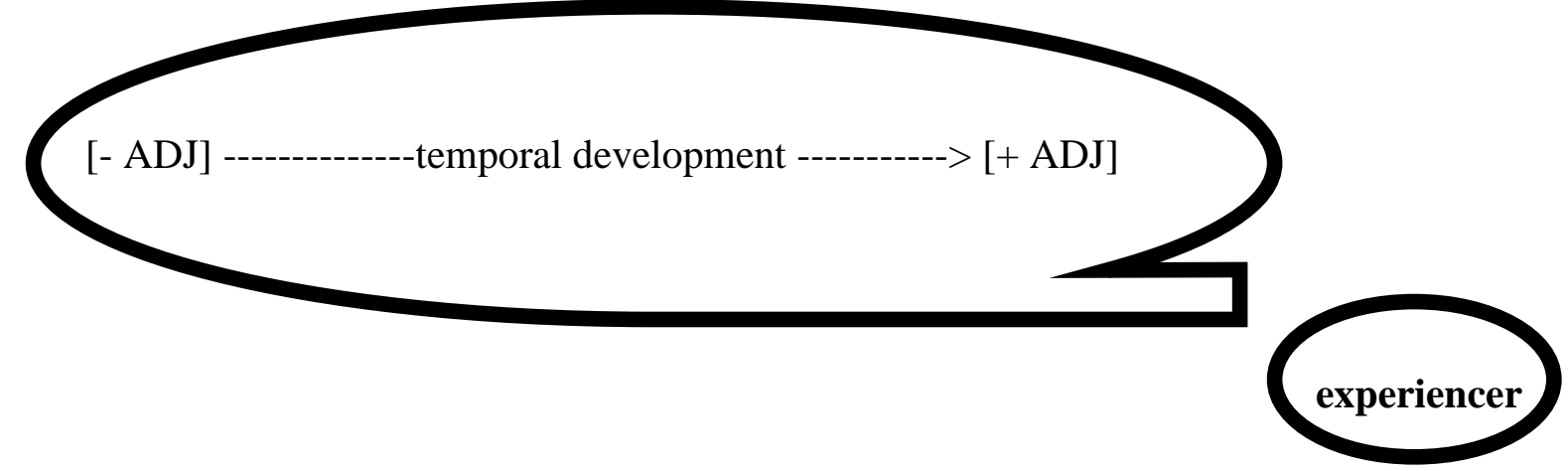

$\underline{\text { FIGURE } 2}$

se faire

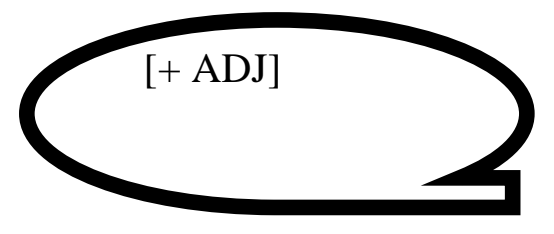

experiencer 